\title{
Interactive comment on "Tsunami damage to ports: Cataloguing damage to create fragility functions from the 2011 Tohoku event" by Constance Ting Chua et al.
}

Constance Ting Chua et al.

cchua020@e.ntu.edu.sg

Received and published: 21 April 2021

We thank the reviewer for the very encouraging comments, and we appreciate the time and effort spent on providing us with a rigorous review. The insights provided were highly beneficial for improving the quality of this manuscript. Please find our responses and corrections to your comments in the supplementary PDF.

Kind regards, Constance Chua, on behalf of all authors

Please also note the supplement to this comment: 
https://nhess.copernicus.org/preprints/nhess-2020-355/nhess-2020-355-AC2supplement.pdf

NHESSD

Interactive comment on Nat. Hazards Earth Syst. Sci. Discuss., https://doi.org/10.5194/nhess2020-355, 2020.

Interactive

comment 